\title{
Optimization of Spruce (Picea abies L.) Wood Thermal Treatment Temperature to Improve Its Acoustic Properties
}

\author{
Przemysław Mania,* Waldemar Moliński, Edward Roszyk, and Marta Górska \\ The study was undertaken to establish the thermal treatment parameters of \\ spruce (Picea abies L.) wood that would ensure the highest possible value \\ of the specific modulus of elasticity $(E / \rho)$ and, thus, the best acoustic \\ performance. The basic acoustic parameters of spruce wood were \\ determined prior to and after its thermal treatment. As a result of thermal \\ treatment, the samples density slightly decreased by about $1 \%$, irrespective \\ of temperature applied. The average value of Young modulus of the samples \\ after modification at 120 to $160{ }^{\circ} \mathrm{C}$ increased from 10.1 to $10.7 \mathrm{GPa}(6 \%)$. \\ The specific modulus of elasticity increased on average by $6.5 \%$. Increase \\ of the modification temperature to $180{ }^{\circ} \mathrm{C}$ resulted in decreasing of the \\ values of mechanical parameters by over $4 \%$.
}

Keywords: Spruce; Specific modulus of elasticity; Acoustic parameters; Thermal modification

Contact information: Department of Wood Science, Faculty of Wood Technology, Poznan University of Life Sciences, Wojska Polskiego 38/42, 60-627 Poznań, Poland;

* Corresponding author: przemyslaw.mania@up.poznan.pl

\section{INTRODUCTION}

Although wood from a few species is used to construct musical instruments, the upper boards of resonance boxes are usually made of spruce wood (Kamiński and Świrek 1972). In stringed instruments, wood is used to enhance the sound of strings by the phenomenon of resonance. The wood suitable for this purpose is characterized by small logarithmic decrement (Mania et al. 2017) and as high as possible specific modulus of elasticity (Bucur 2006), defined as the ratio of $E / \rho$. The acoustic parameters used to evaluate resonant wood quality for the construction of stringed instruments, including violins, are velocity of sound propagation $(V=\sqrt{ }(E / \rho))$, acoustic impedance $(Z=\rho \sqrt{ }(E / \rho))$ and acoustic constant $\left(A=\sqrt{ }\left(E / \rho^{3}\right)\right)$. The modulus of elasticity and density appear in all acoustical parameters describing the suitability of wood for production of resonance boards. It is convenient to use the specific modulus of elasticity $\left(E_{s p}\right)$ as an indicator of good quality resonant wood. The best resonant wood should have a high value of modulus of elasticity $(E)$ and a low density of approximately $400 \mathrm{~kg} / \mathrm{m}^{3}$ (Bucur 2006).

The choice of thermally modified wood for construction of stringed musical instruments follows from its properties. Such wood is characterized by decreased density and reduced hygroscopicity, which improve the dimensional stability of the instrument. During thermal modification of wood, its density decreases, and after a relatively mild treatment, its linear modulus of elasticity and hardness may increase (Viitaniemi et al. 1997; ThermoWood® Handbook 2003; Boonstra et al. 2007; Windeisen et al. 2009). The decrease in density as a result of thermal modification is related to evaporation of side components of wood, such as terpenes, fat, wax, and phenols that evaporate and the 
products of decomposition of the least stable hemicelluloses. A significant reduction of hemicelluloses - the most hydrophilic component of wood-leads to a considerable decrease in hygroscopicity of the modified wood, through reduces the contribution of hydroxyl groups $(\mathrm{OH})$ that are responsible for binding water (Kollmann and Fengel 1965; Moliński et al. 2010; Moliński et al. 2016). The above-mentioned changes caused by thermal modification of wood could improve its acoustic parameters, i.e., sound velocity, acoustic impedance, and acoustic constant. Therefore, it can be expected that proper choice of thermal treatment temperature may increase the value of $E / \rho$ and improve the acoustic performance of wood. Moreover, the literature provides reports on attempts at diminishing of the wood inhomogeneity and improving the ratio of the elasticity modulus to density (E/ $\rho$ ) (Nagyvary et al. 2006; Spycher et al. 2008; Schwarze et al. 2008; Stoel and Borman 2008).

In this study, the intention was to experimentally select the parameters of thermal modification at which the highest value of the specific modulus of elasticity $\left(E_{s p}\right)$ would be obtained, thus improving the acoustic parameters. Therefore, the basic mechanical parameters of wood before and after its thermal treatment were determined in the tests.

\section{EXPERIMENTAL}

\section{Materials and Methods}

The study was performed for eight radially cut planks from spruce wood of different suitability for resonance boards. The specimens were obtained from trees growing in the Eastern Romanian Carpathians near Maramures, which produce high quality resonant wood (Bielczyk and Bobrowicz 1960). All planks were classified by luthiers to three groups of resonant wood quality, classes I, II and III, according to BN-70/9221-06 (1970). The planks were also characterized by different widths of annual rings and different latewood percentage.

Physical and mechanical properties were determined for wood samples of the size 10 (radial) $\times 10$ (tangential) $\times 150$ (longitudinal) $\left(\mathrm{mm}^{3}\right)$ obtained from each plank and conditioned at $20{ }^{\circ} \mathrm{C}$ and a relative humidity (RH) of $50 \pm 2 \%$ for 2 months. The cutting method is illustrated in Fig. 1.

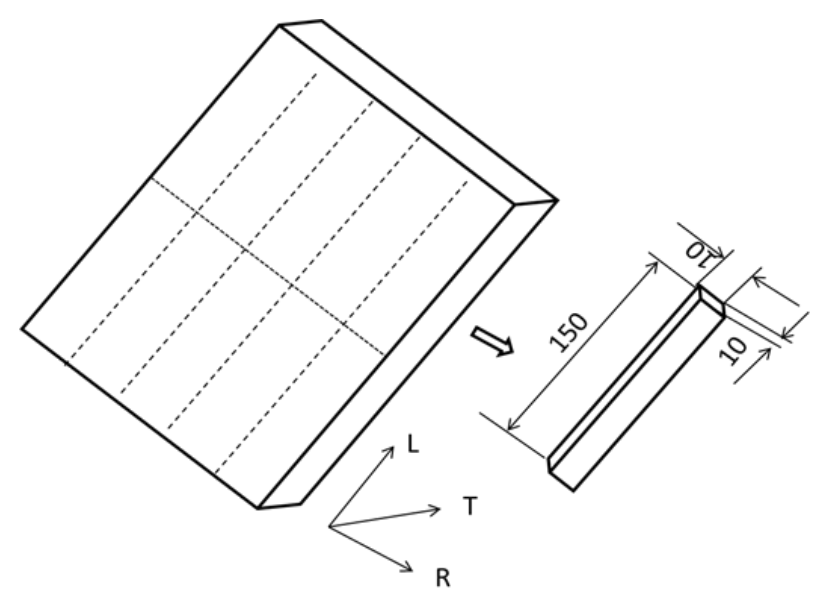

Fig. 1. The way of sample preparation 
The sample density was determined according to ISO 13061-2 (2014). The mass of each sample was measured on an analytical balance (Sartorius $\mathrm{GmbH}$, Goettingen, Germany) ( $\pm 0.001 \mathrm{~g}$ accuracy). The dimensions were measured with a digital caliper to the accuracy of $\pm 0.01 \mathrm{~mm}$. The moisture content of the samples varied from 8.5 to $9.2 \%$.

The modulus of elasticity of the samples $\left(10 \times 10 \times 150 \mathrm{~mm}^{3}\right)$ was measured in a static bending test after conditioning $\left(20{ }^{\circ} \mathrm{C}, 50 \% \mathrm{RH}\right)$. The bending force direction was tangent to the annual rings, and its value was $120 \mathrm{~N}$. This value was established in preliminary studies performed on 15 samples subjected to full bending test, until damage, reading off the force value at the border of proportionality. The bending of samples with the force smaller than that at the border of proportionality does not result in permanent deformation, so it was possible to use the samples again for measurements of the elasticity modulus after modification. The tests were performed on a universal mechanical strength testing machine (Zwick Z050TH, Ulm, Germany) prior to and after sample modification. The distance between the supports during the test was $120 \mathrm{~mm}$, while the load was placed exactly in the middle between the supports. The rate of loading was chosen in such a way to complete the test in about $90 \mathrm{~s}$.

The test machine output was used to calculate the modulus of elasticity, according to Eq. 1,

$$
E=\frac{\Delta F l^{3}}{4 \Delta f a h^{3}}(\mathrm{MPa})
$$

where $\Delta F$ is the load difference $(\mathrm{N}), \Delta f$ is the increment of the sample deflection $(\mathrm{mm}), a$ is the sample width in radial direction $(\mathrm{mm})$, and $h$ is the sample height in tangential direction $(\mathrm{mm})$.

The specific modulus of elasticity was defined as follows,

$$
E_{s p}=E / \rho(\mathrm{kNm} / \mathrm{kg}) \text {. }
$$

where $\rho$ is the wood density.

Basic acoustic parameters were calculated on the basis of the relevant physical parameters. The sound propagation velocity $(V)$ was calculated from the formula:

$$
V=\sqrt{\frac{E}{\rho}}(\mathrm{m} / \mathrm{s})
$$

Acoustic impedance was defined as,

$$
Z=V \times \rho=\rho \times \sqrt{\frac{E}{\rho}}\left(\mathrm{kg} / \mathrm{m}^{2} \mathrm{~s}\right),
$$

and acoustic constant as:

$$
\mathrm{A}=\sqrt{\frac{E}{\rho^{3}}}\left(\mathrm{~m}^{4} / \mathrm{kgs}\right)
$$

After determination of the $E$, the samples were subjected to thermal modification in a steam atmosphere, based on the ThermoWood procedure (Viitaniemi et al. 1997; González-Peña and Hale 2007; Boonstra 2008; Moliński et al. 2010). Different variants of wood modification were carried out in laboratory conditions at $120{ }^{\circ} \mathrm{C}, 140{ }^{\circ} \mathrm{C}, 160{ }^{\circ} \mathrm{C}$, and $180{ }^{\circ} \mathrm{C}$, which were applied for $3 \mathrm{~h}$. At first the planks were heated to achieve a temperature of $110{ }^{\circ} \mathrm{C}$ in their bulk. The temperature was maintained for $2 \mathrm{~h}$ to get wood moisture content at a level of about $1 \%$, then the temperature was increased to a desired 
value and maintained for $3 \mathrm{~h}$. After completion of heating at a constant temperature, the heating was turned off. After the decrease of temperature, the influx of steam was stopped and the planks were kept in the chamber until their temperature reached that of the ambient. Each variant of modification was applied to 30 samples representing the three quality groups, with 10 samples in each class. The average density and macrostructural parameters of all samples were similar in each variant. After modification, the density and modulus of elasticity of all samples were measured. The samples were conditioned under the same conditions before and after modification, but the processes taking place in wood, mainly at $180{ }^{\circ} \mathrm{C}$, reduced the equilibrium moisture content (EMC) of the wood. Mechanical parameters of wood to a high degree depend on the moisture content, so they were determined at the same EMC. For this reason, the samples subjected to modification at 180 ${ }^{\circ} \mathrm{C}$ were conditioned in a desiccator in the presence of $\mathrm{NaNO}_{3}\left(20{ }^{\circ} \mathrm{C}, \mathrm{RH}=\sim 70 \%\right)$, which ensured that the moisture content of these samples was approximately $8.5 \%$. Prior to modification, the moisture content of the samples varied from 8.5 to $9.1 \%$, while after modification it ranged from 8.3 to $8.8 \%$.

The experimental data were analyzed using the Dell ${ }^{\mathrm{TM}}$ Statistica ${ }^{\mathrm{TM}} 13.1$ software with the analysis of variance (ANOVA). Significant differences between mean values of the parameters describing the properties of treated and untreated samples were determined using Tukey's HSD test. The comparison tests were performed at a 0.05 significance level.

\section{RESULTS AND DISCUSSION}

An important feature for wood classification with regard to its suitability for musical instruments is the equality of its annual rings (Table 1). In the samples classified as resonance wood, the annual rings widths varied from $1.21 \mathrm{~mm}$ to $1.91 \mathrm{~mm}$. The deviation between the maximum and minimum annual ring width were also different for different classes. Narrower rings were noted for class I $(0.8 \mathrm{~mm})$, while the widest were observed for class III (1.4 mm).

Table 1. Macrostructural Parameters of Spruce Wood

\begin{tabular}{|c|c|c|c|c|c|c|}
\hline $\begin{array}{c}\text { Quality } \\
\text { Class }\end{array}$ & Macrostructure & Mean & Min. & Max. & $\begin{array}{c}\text { Standard } \\
\text { Deviation }\end{array}$ & $\begin{array}{c}\text { Coefficient of Variation } \\
\text { V (\%) }\end{array}$ \\
\hline \multirow{2}{*}{ I } & rw & $\mathbf{1 . 2 1}$ & 0.85 & 1.67 & 0.26 & 21.5 \\
\cline { 2 - 7 } & Iwp & $\mathbf{1 5 . 0}$ & 8.5 & 17.4 & 2.74 & 18.3 \\
\hline \multirow{2}{*}{ II } & rw & $\mathbf{1 . 4 8}$ & 0.98 & 2.02 & 0.33 & 22.3 \\
\cline { 2 - 7 } & Iwp & $\mathbf{1 9 . 6}$ & 9.2 & 26.7 & 5.12 & 26.1 \\
\hline \multirow{2}{*}{ III } & rw & $\mathbf{1 . 9 1}$ & 0.97 & 2.41 & 0.48 & 25.1 \\
\cline { 2 - 6 } & Iwp & $\mathbf{2 5 . 2}$ & 12.8 & 28.8 & 4.30 & 17.1 \\
\hline
\end{tabular}

Note: rw, ring width (mm), Iwp, the latewood percentage (\%)

In addition to the uniform width of annual rings, the resonance wood should show poorly developed latewood. The basic statistical data on these parameters are given in Table 1. The most uniform material was wood of class I. The difference between the maximum and minimum contribution of latewood was only $9 \%$.

It is generally assumed that with increasing width of annual rings in coniferous species, the percentage of latewood decreases (Kollmann and Cóte 1984), but in the material studied the reverse was true. The smallest contribution of latewood was noted in 
the wood of the narrowest annual rings. The reason for this difference can be difficult growth conditions for the trees supplying the wood. The wood from high-mountain spruce trees is characterized by poorly developed latewood. Because of the short vegetation period, the wood shows narrow annual rings of poorly developed latewood, which is desired in good quality resonance wood. The latewood percentage below $20 \%$ is characteristic of good resonance wood (Holz 1984). Spycher et al. (2008) observed that in some high quality resonance wood the latewood is made of only 4 to 6 tracheids in the radial direction of a ring.

Figure 2 presents the histograms of density distribution in the wood from each class. The wood from class I showed the lowest density in the range 380 to $430 \mathrm{~kg} / \mathrm{m}^{3}$, and in class II wood the density varied from 410 to $460 \mathrm{~kg} / \mathrm{m}^{3}$. In class III, the density varied from 520 to $580 \mathrm{~kg} / \mathrm{m}^{3}$. The above differences are directly related to the above-discussed macrostructural parameters of annual rings, mainly to the latewood percentage. In all samples studied, the density distribution was similar to normal, with the expected value (mean) $\mu$ and variance $\sigma^{2}$, which is often denoted as $\mathrm{N}\left(\mu ; \sigma^{2}\right)$ (Fig. 2).

The sample density slightly decreased as a result of thermal treatment, which confirms earlier reports (Gündüz et al. 2008; Gonzalez- Pena and Hale 2009). The mean values of wood density before $(\rho)$ and after thermal treatment $\left(\rho_{M O D}\right)$ are given in Table 2.

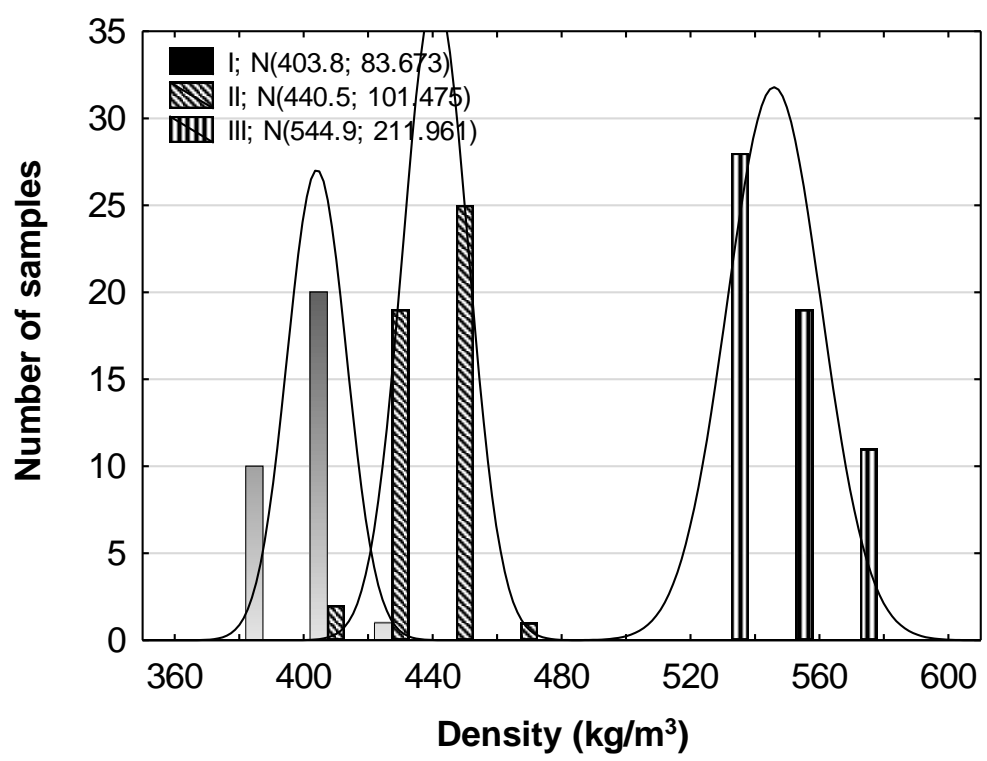

Fig. 2. Histograms of density distribution in individual quality classes of resonance wood

Table 2. Mean Value of Spruce Wood Density Prior to and After Modifications at Different Temperatures

\begin{tabular}{|c|c|c|c|c|c|c|c|c|c|}
\hline \multirow{4}{*}{$\begin{array}{l}\text { Modification } \\
\text { Temperature }\end{array}$} & \multicolumn{9}{|c|}{ Quality Class } \\
\hline & \multicolumn{3}{|c|}{ I } & \multicolumn{3}{|c|}{ II } & \multicolumn{3}{|c|}{ III } \\
\hline & $\rho$ & $\rho_{\mathrm{MOD}}$ & $\Delta \rho$ & $\rho$ & $\rho_{\mathrm{MOD}}$ & $\Delta \rho$ & $\rho$ & $\rho_{\text {MOD. }}$ & $\Delta \rho$ \\
\hline & \multicolumn{2}{|c|}{$\left(\mathrm{kg} / \mathrm{m}^{3}\right)$} & $(\%)$ & \multicolumn{2}{|c|}{$\left(\mathrm{kg} / \mathrm{m}^{3}\right)$} & $(\%)$ & \multicolumn{2}{|c|}{$\left(\mathrm{kg} / \mathrm{m}^{3}\right)$} & $(\%)$ \\
\hline $120^{\circ} \mathrm{C}$ & 405 & 396 & -2.2 & 436 & 428 & -1.8 & 545 & 540 & -0.9 \\
\hline $140^{\circ} \mathrm{C}$ & 404 & 398 & -1.5 & 436 & 432 & -0.9 & 544 & 537 & -1.3 \\
\hline $160^{\circ} \mathrm{C}$ & 405 & 400 & -1.2 & 437 & 431 & -1.4 & 545 & $536^{*}$ & -1.7 \\
\hline $180^{\circ} \mathrm{C}$ & 403 & $387^{*}$ & -4.0 & 442 & 421 & -4.8 & 543 & 529 & -2.6 \\
\hline
\end{tabular}

${ }^{*}$ Significant differences 
The range of density change, $\Delta \rho$ was calculated as follows,

$$
\Delta \rho=\frac{\rho_{M O D}-\rho}{\rho}
$$

The thermal treatment at 120 to $160{ }^{\circ} \mathrm{C}$ caused a slight decrease in wood density, by about $1 \%$, irrespective of the quality class. The treatment at $180{ }^{\circ} \mathrm{C}$ for the same time reduced the wood density on average by $3.4 \%$, and the greatest density decrease, by almost $5 \%$, was noted for wood of quality class II. The reduction of wood density as a result of its thermal modification was not a linear function of temperature. The ANOVA variance analysis was performed for the density changes of modified and unmodified wood representing the three quality classes. Although the arithmetic means of wood density before and after modification were different for the samples studied, according to the ANOVA analysis at the level of significance of 0.05 , the differences were significant only for two variants. Thus, thermal modification of the resonance spruce wood at the applied temperatures may cause small changes in density. A decrease in the pine wood density by about $3.5 \%$ at $160{ }^{\circ} \mathrm{C}$, has been described by e.g. Zawadzki et al. (2013), while Icel et al. (2015) after thermal modification of spruce wood at $190{ }^{\circ} \mathrm{C}$ have observed a decrease in wood density by about $3 \%$. The decrease in density was found to be lower for spruce wood than for pine wood. This result can also be explained by the lower extractives content of spruce wood (Sehlstedt-Persson 2003).

As the wood density decreases upon thermal treatment, its mechanical parameters are expected to deteriorate. Table 3 presents the modulus of elasticity determined along the grains for the wood before $(E)$ and after thermal treatment $\left(E_{M O D}\right)$ at different temperatures.

Table 3. Mean Values of Modulus of Elasticity of Wood Samples Before and After Thermal Modification at Different Temperatures

\begin{tabular}{|c|c|c|c|c|c|c|c|c|c|}
\hline \multirow{4}{*}{$\begin{array}{l}\text { Modification } \\
\text { Temperature }\end{array}$} & \multicolumn{9}{|c|}{ Wood Quality Class } \\
\hline & \multicolumn{3}{|c|}{1} & \multicolumn{3}{|c|}{ II } & \multicolumn{3}{|c|}{ III } \\
\hline & $E$ & $E_{\mathrm{MOD}}$ & $\Delta E$ & $E$ & $E_{\mathrm{MOD}}$ & $\Delta E$ & $E$ & $E_{M O D}$ & $\Delta E$ \\
\hline & \multicolumn{2}{|c|}{ (MPa) } & $(\%)$ & \multicolumn{2}{|c|}{$(\mathrm{MPa})$} & $(\%)$ & \multicolumn{2}{|c|}{$(\mathrm{MPa})$} & $(\%)$ \\
\hline $120^{\circ} \mathrm{C}$ & 7635 & $8236^{*}$ & 7.9 & 9767 & 10038 & 2.8 & 12838 & 13462 & 4.9 \\
\hline $140^{\circ} \mathrm{C}$ & 7975 & $8494^{*}$ & 6.5 & 9561 & $10104^{*}$ & 5.7 & 13084 & $13747^{\star}$ & 5.1 \\
\hline $160^{\circ} \mathrm{C}$ & 7860 & 8424 & 7.2 & 9728 & 10225 & 5.1 & 12700 & 13307 & 4.8 \\
\hline $180^{\circ} \mathrm{C}$ & 8109 & 7784 & -4.0 & 10102 & 9669 & -4.3 & 13004 & 12452 & -4.2 \\
\hline
\end{tabular}

${ }^{*}$ Significant differences

The thermal treatment at temperatures below $180{ }^{\circ} \mathrm{C}$ resulted in increasing values of the wood modulus of elasticity. The mean value of Young modulus after modification at 120 to $160{ }^{\circ} \mathrm{C}$ increased from 10.1 to $10.7 \mathrm{GPa}(6 \%)$. Analysis of the changes in modulus of elasticity in particular classes of resonance wood quality revealed that the greatest increase in this parameter for the sample of the lowest density representing class I. This increase was $7.9 \%$ for the treatment at $120{ }^{\circ} \mathrm{C}, 6.5 \%$ at $140{ }^{\circ} \mathrm{C}$, and $7.2 \%$ at $160{ }^{\circ} \mathrm{C}$. After modification at $180{ }^{\circ} \mathrm{C}$, the elasticity modulus decreased, and the decrease was close to $4.3 \%$, irrespective of the wood quality class. An increase in the elasticity modulus upon modification at $190{ }^{\circ} \mathrm{C}$ has been confirmed by Navickas et al. (2015), who reported a growth of $E$ by about $0.5 \%$. A positive effect of thermal modification on the modulus of elasticity, not only of spruce wood, has been confirmed by e.g. Shi et al. (2007) and Kol et al. (2015). According to the ANOVA variance analysis, the differences in modulus of elasticity before and after modification were statistically significant in only four variants 
of modification. A statistically insignificant increase in the modulus of elasticity after thermal modification of spruce wood has been reported by Bekhta and Niemz (2003).

The modulus of elasticity values were analyzed as a function of wood density, before and after modification. The relationship between these two parameters for wood samples of similar moisture content are presented in Fig. 3.
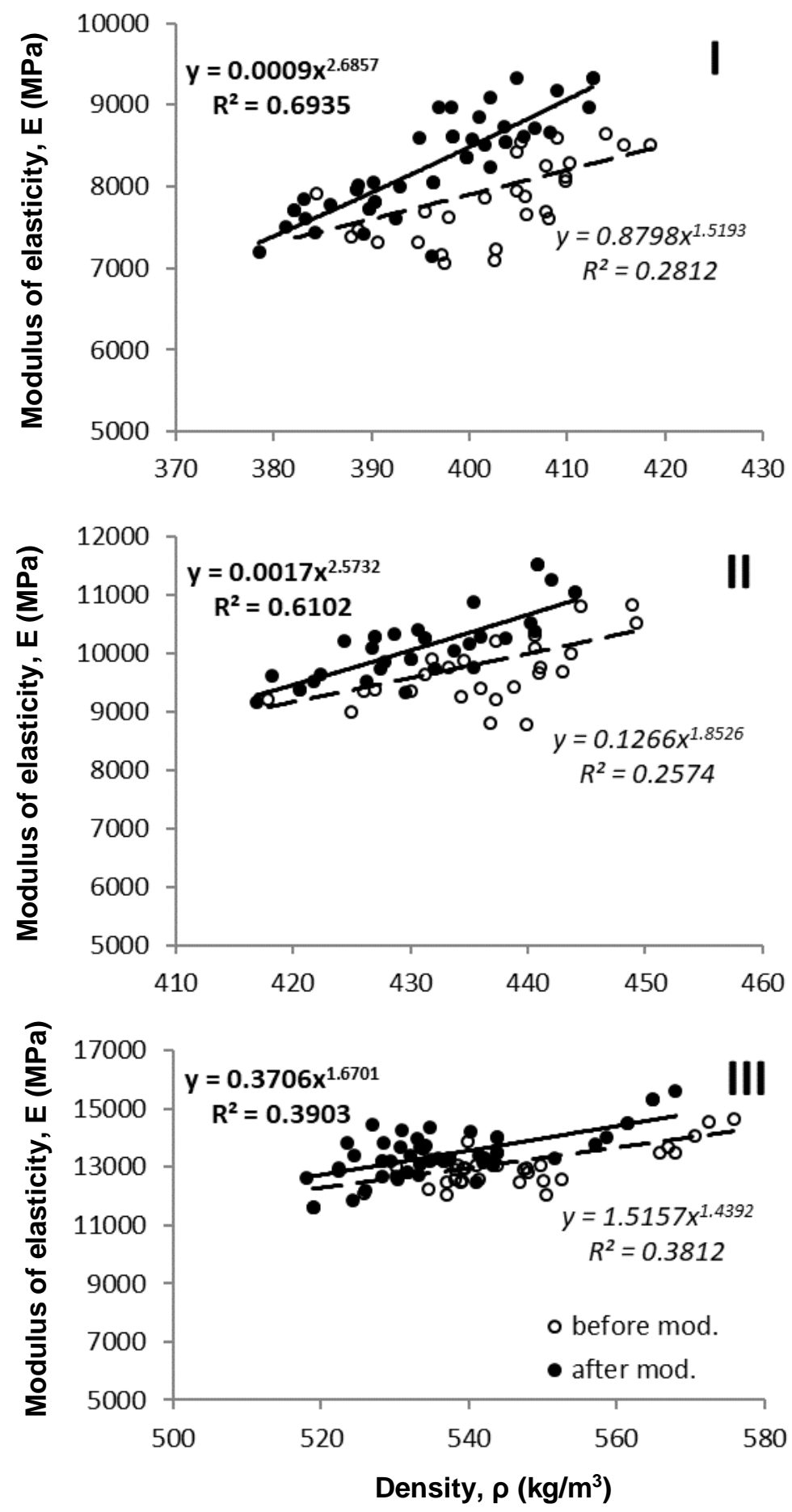

Fig. 3. Relationship between the modulus of elasticity and density of wood before and after its modification, for wood quality classes I, II, and III 
Assuming that the power functions selected on the basis of the highest determination coefficient approximate these relations well, it can be concluded that the thermal modification resulted in clarification of the relationship between the modulus of elasticity and density of wood. This conclusion is supported by the fact that the coefficients of determination were higher for the modified than for unmodified wood. Thus it can be also concluded that thermal modification increased the uniformity of the wood samples. The greatest improvement in the quality of relationship between the modulus of elasticity and density was noted for wood representing classes I and II, i.e., for wood samples of lower density. Prior to the thermal treatment the modulus of elasticity values determined for these samples were much more scattered. Notably, the value of exponent $n$ in the function $f(x)=x^{n}$ describes the relationship between the modulus of elasticity and density; it takes the highest value for wood samples representing class I (2.6857), lower for class II (2.5732), and the lowest for class III (1.6701). These values indicate that for the high quality resonance spruce wood, the relationship between the modulus of elasticity and density depends on other factors. The power function with the exponent of nearly 2.7 for samples in class I may indicate a significant impact of the microfibril angle $(M F A)$ on the modulus of elasticity. Hence, the wood density is not the only determinant of its mechanical properties, as reported earlier (Raczkowski 1965; Zhang 1997; Roszyk et al. 2010; Krauss and Kúdela 2011; Roszyk et al. 2012; Fabisiak and Mania 2016). The impact of MFA is particularly pronounced for the wood of higher density, i.e., in latewood with smaller MFA values.

Good resonance wood is characterized by high modulus of elasticity at the lowest possible density. According to the results, the thermal modification of wood improved the ratio of these two parameters. The modulus of elasticity and density appear in all parameters describing the suitability of wood for production of resonance boards. It is convenient to use the specific modulus of elasticity defined as the ratio of $E / \rho$. The mean values of specific modulus of elasticity calculated for all samples are presented in Table 4.

Table 4. Mean Values of Specific Modulus of Elasticity of Wood Samples Studied Before (n.mod) and After Modification (mod.) at Different Temperatures

\begin{tabular}{|c|c|c|c|c|c|c|c|c|c|}
\hline \multirow{4}{*}{$\begin{array}{l}\text { Modification } \\
\text { Temperature }\end{array}$} & \multicolumn{9}{|c|}{ Quality Class } \\
\hline & \multicolumn{3}{|c|}{ I } & \multicolumn{3}{|c|}{ II } & \multicolumn{3}{|c|}{ III } \\
\hline & n.mod & mod. & $\Delta\left(E_{\mathrm{sp}} / \rho\right)$ & n.mod & mod. & $\Delta\left(E_{\mathrm{sp}} / \rho\right)$ & n.mod & mod. & $\Delta\left(E_{\mathrm{sp}} / \rho\right)$ \\
\hline & \multicolumn{2}{|c|}{$(\mathrm{kNm} / \mathrm{kg})$} & (\%) & \multicolumn{2}{|c|}{$(\mathrm{kNm} / \mathrm{kg})$} & $(\%)$ & \multicolumn{2}{|c|}{$(\mathrm{kNm} / \mathrm{kg})$} & $(\%)$ \\
\hline $120^{\circ} \mathrm{C}$ & 18.87 & 20.80 & 10.2 & 22.41 & 23.40 & 4.4 & 23.54 & 24.92 & 5.9 \\
\hline $140^{\circ} \mathrm{C}$ & 19.75 & 21.31 & 7.9 & 21.93 & 23.39 & 6.7 & 24.04 & 25.61 & 6.5 \\
\hline $160^{\circ} \mathrm{C}$ & 19.39 & 21.04 & 8.5 & 22.23 & 23.74 & 6.8 & 23.27 & 24.84 & 6.7 \\
\hline $180^{\circ} \mathrm{C}$ & 20.12 & 20.11 & -0.05 & 22.86 & 22.97 & 0.5 & 23.95 & 23.54 & -1.7 \\
\hline
\end{tabular}

The mean values of specific modulus of elasticity before the modification for wood samples representing particular quality classes were $19.53,22.36$, and $23.70 \mathrm{kNm} / \mathrm{kg}$. For the majority of variants, thermal modification increased the value of this parameter. The exception is the effect of thermal treatment at $180{ }^{\circ} \mathrm{C}$, after which in wood samples of class I and II the value of specific modulus of elasticity remained practically unchanged, while in wood samples of class III it decreased by $2 \%$. The greatest changes in the specific modulus of elasticity were found in the wood samples of the highest quality, for which $E / \rho$ increased on average by $9 \%$ as a result of modifications at 120 to $160{ }^{\circ} \mathrm{C}$. The 
corresponding increase in the $E_{s p}$ for the samples of classes II and III after modification in the same conditions reached on average $6.5 \%$. The greatest increase in the specific modulus of elasticity for the wood samples of all quality classes was noted at the modification at $160{ }^{\circ} \mathrm{C}$, so the basic acoustic parameters were calculated only for this temperature of modification.

The results showed that thermal treatment at an appropriate temperature leads to an increase in the specific modulus of elasticity and thus improves all other acoustic parameters. Table 5 presents the acoustic parameters of the resonance spruce wood of different classes of quality, calculated for the modification temperature of $160{ }^{\circ} \mathrm{C}$. Also the percentage differences $(\Delta)$ between the acoustic parameters before and after modification are included.

Table 5. Mean Values of Sound Velocity ( $V$ ), Acoustic Impedance (Z), and Acoustic Constant $(A)$ of Wood Samples Studied Before (n.mod) and After Modification (mod.) at $160^{\circ} \mathrm{C}$

\begin{tabular}{|c|c|c|c|c|c|c|c|c|c|}
\hline \multirow{2}{*}{$\begin{array}{c}\text { Acoustic } \\
\text { Parameter }\end{array}$} & \multicolumn{9}{|c|}{ Quality Class } \\
\cline { 2 - 11 } & \multicolumn{3}{|c|}{$\mathrm{I}$} & \multicolumn{3}{c|}{ II } & \multicolumn{3}{c|}{ III } \\
\cline { 2 - 11 } & n.mod & mod. & $\Delta$ & n.mod & mod. & $\Delta$ & n.mod & mod. & $\Delta$ \\
\hline$V(\mathrm{~m} / \mathrm{s})$ & 4400 & 4584 & +4.18 & 4714 & 4872 & +3.35 & 4820 & 4982 & +3.36 \\
\hline$Z\left(\mathrm{~kg} / \mathrm{m}^{2 *} \mathrm{~s}\right)^{*} 10^{5}$ & 17.84 & 18.35 & +2.86 & 20.62 & 20.98 & +1.75 & 26.30 & 26.96 & +2.51 \\
\hline$A\left(\mathrm{~m}^{4} / \mathrm{kg}^{*} \mathrm{~s}\right)$ & 10.86 & $11.46^{*}$ & +5.52 & 10.78 & $11.32^{*}$ & +5.01 & 8.84 & $9.30^{*}$ & +5.20 \\
\hline
\end{tabular}

* Significant differences

Analysis of the data presented in Table 5 justifies the distinction of the wood studied in the quality classes. High quality resonance wood should be characterized by the lowest possible acoustic impedance and the highest possible acoustic constant (Bucur 2006).

Thermal modification at $160{ }^{\circ} \mathrm{C}$ brought about an increase in all basic acoustic parameters of the resonance spruce wood. The greatest differences were observed in the acoustic constant, which after thermal treatment had been increased by about $5.2 \%$. Only the differences in this parameter were statistically significant for wood of all quality classes. The acoustic constant determines the wood suitability for construction of resonance musical instruments, and for good resonance wood it should be higher than 10 . The increase by about $3.6 \%$ was found for the sound velocity. The smallest changes were observed in the acoustic impedance increased as a result of heat treatment by about $2.4 \%$, which is beneficial for the resonance wood, as it does not affect the damping of vibrations of particles and sound wave (Holz 1973). What is more, in first class wood, the greatest increase in the acoustic parameters was noted.

Similar observations have been reported by Pfriem et al. (2007) who studied the effects of modification of spruce wood. Mohebby et al. (2007) have reported an improvement in acoustic parameters of modified wood of mulberry tree. Zauer et al. (2014) studied the effects of thermal treatment of beechwood at $140{ }^{\circ} \mathrm{C}$ and $160{ }^{\circ} \mathrm{C}$, showing the improvement in its acoustic properties to the values characteristic of maple wood used for construction of elements of musical instruments. 


\section{CONCLUSIONS}

1. The best improvement in the acoustic parameters for the spruce wood samples of all quality classes were achieved as a result of thermal modification at $160{ }^{\circ} \mathrm{C}$. After this treatment the increase in the modulus of elasticity and acoustic constant was the highest.

2. Thermal modification can further improve acoustic parameters of the highest quality wood, which may bring even better acoustic performance of instruments made of it.

3. The use of thermally modified wood for construction of musical instruments is justified by the qualities of the modified product showing lower density and reduced hygroscopicity, which increases the stability of the instrument dimensions.

\section{ACKNOWLEDGEMENTS}

The paper was financed within the framework of Ministry of Science and Higher Education programme 'Regional Initiative of Excellence' in years 2019-2022, Project No. 005/RID/2018/19.

\section{REFERENCES CITED}

Bekhta, P., and Niemz, P. (2003), "Effect of high temperature on the change in color, dimensional stability and mechanical properties of spruce wood," Holzforschung, 57(5), 539-546.

Bielczyk, S., and Bobrowicz, E., (1960). "Badania niektórych właściwości świerkowego drewna rezonansowego pochodzenia polskiego i rumuńskiego," Prace Instytutu Technologii Drewna 2(18). PWN Poznań. (in Polish)

BN-70/9221-06 (1970). "Drewno rezonansowe z drzew iglastych,” Polski Komitet Normalizacyjny, Warsaw, Poland. (in Polish)

Boonstra, M. J., Van Acker, J., Tjeerdsma, B. F., and Kegel, E. F. (2007). "Strength properties of thermally modified softwoods and its relation to polymeric structural wood constituents," Ann. For. Sci. 64(7), 679-690. DOI: 10.1051/forest:2007048

Boonstra, M. J. (2008). A Two-stage Thermal Modification of Wood, Ph.D. Dissertation Ghent University, Ghent, Belgium.

Bucur, V. (2006). Acoustics of Wood ( $2^{\text {nd }}$ Ed.), Springer Verlag, Berlin, Germany. DOI: 10.1007/3-540-30594-7

Fabisiak, E., and Mania, P. (2016). "Variation in the microfibril angles in resonance and non-resonance spruce wood (Picea abies [L.] Karst.)," BioResources 11(4), 84968508. DOI: 10.15376/biores.11.4.8496-8508

González-Peña, M. M., and Hale, M. D. C. (2007). "The relationship between mechanical performance and chemical changes in thermally modified wood," in: The Third European Conference on Wood Modification, Cardiff, UK, 169-172.

González-Peña, M. M., and Hale, M. D. C. (2009). "Colour in thermally modified wood of beech, Norway spruce and Scots pine. Part 2: Property predictions from colour changes," Holzforschung 63(4), 394-401. DOI: 10.1515/HF.2009.077

Gündüz, G, Korkut, S, and Korkut, D. S. (2008). "The effects of heat treatment on physical and technological properties and surface roughness of Camiyanı Black Pine 
(Pinus nigra Arn. subsp. pallasiana var. pallasiana) wood," Bioresour Technol. 99(7), 2275-2280. DOI: 10.1016/j.biortech.2007.05.015

Holz, D. (1984). “On some relations between anatomic properties and acoustical qualities of resonance wood," Holztechnologie 25(1), 31-36.

Holz, D. (1973). "Akustische Eigenschaften von Resonanzholz. Zur Beurteilung von Resonanzhölzern und einigen vergleichbaren Austausch- werkstoffen durch Messung akustisch wichtiger Eigenschaften," Holztechnologie 14(2), 113-114.

Icel, B., Guler, G., Isleyen, O., Beram, A., and Mutlubas, M. (2015). "Effect of industrial heat treatment on the properties of spruce and pine woods," BioResources 10(3), 5159-5173. DOI: 10.15376/biores.10.3.5159-5173

ISO 13061-2 (2014). "Physical and mechanical properties of wood - Test methods for small clear wood specimens - Part 2: Determination of density for physical and mechanical tests," International Organization for Standardization, Geneva, Switzerland.

Kamiński, W., and Świrek, J., (1972). ’Lutnictwo: Wstęp do sztuki lutniczej,” Polskie Wydawnictwo Muzyczne Kraków, Poland. (in Polish)

Kol, H. S., Sefil, Y., and Keskin S. A. (2015). "Effect of heat treatment on the mechanical properties, and dimensional stability of fir wood," in: The 27th International Conference Research for Furniture Industry, Turkey 269-279.

Kollmann, F., and Côté, W. A. (1968). Principles of Wood Science and Technology, Springer Verlag, Berlin, Germany. DOI: 10.1007/978-3-642-87928-9

Kollmann, F., and Fengel, D., (1965). "Changes in the chemical composition of wood by heat treatment," Holz Roh- und Werkstoff 12, 461-468.

Krauss, A., and Kúdela, J. (2011). 'Ultrasonic wave propagation and Young's modulus of elasticity along the grain of Scots pine wood (Pinus sylvestris L.) varying with distance from the pith," Wood Research 56(4), 479-488.

Navickas, P., Karpavičiūtè, S., and Albrektas, D. (2015). "Effect of heat treatment on wettability and modulus of elasticity of pine and spruce wood," Materials Science 21(3), 400-404.

Mania, P., Fabisiak, E., and Skrodzka, E. (2017). "Investigation of modal behaviour of resonance Spruce wood samples (Picea abies L.)," Archives of Acoustics 42(1), 23 28. DOI: $10.1515 /$ aoa-2017-0003.

Mohebby, B., Yaghoubi, K., and Roohnia, M. (2007). "Acoustic properties of hydrothermally modified mulberry (Morus alba L.) wood," Proceedings of the Third Europe-an Conference on Wood Modification, Cardiff, UK, 283-286.

Moliński, W., Fabisiak, E., and Szwaba, T. (2010). "Properties of thermally modified Ash Wood (Fraxinus americana) in the aspect of its affinity to water," Annals of WULS. Forestry and Wood Technol. 72, 27-31.

Moliński, W., Roszyk, E., Jabłoński, A., Puszyński, J., and Cegieła, J. (2016). "Mechanical parameters of thermally modified ash wood determined by compression in radial direction," Maderas. Ciencia y tecnología. 18(4), 577-586. DOI: 10.4067/S0718-221X2016005000050

Nagyvary, J., DiVerdi, J. A., Owen, N. L., and Tolley, H. D. (2006). "Wood used by Stradivari and Guarneri," Nature 30, 444(7119), 565.

Pfriem, A., Eichelberger, K., and Wagenführ, A. (2007). "Acoustic properties of thermally modified spruce for use for violins," Journal of the Violin Society of America 21(1), 102-111.

Raczkowski, J., (1965). "Investigations on the wood cyclic heterogeneity of softwood," 
Rozprawy naukowe WSR Poznań (in Polish).

Roszyk, E., Mania P., and Moliński W. (2012). "The influence of microfibril angle on creep of wood under tensile stress along the grains," Wood Research 57(3), 347-358.

Roszyk, E., Moliński, W., and Jasińska, M. (2010). "The effect of microfibril angle on hygromechanic creep of wood under tensile stress along the grains," Wood Research 55(3), 13-24.

Schwarze, F. W. M. R., Spycher, M., and Fink, S. (2008). "Superior wood for violins wood decay fungi as a substitute for cold climate," New Phytol. 179, 1095-1104. DOI: 10.1111/j.1469-8137.2008.02524.x

Sehlstedt-Persson, M. (2003). "Colour responses to heat-treatment of extractives and sap from pine and spruce," 8 th International IUFRO Wood Drying Conference, Brasov, Romania, pp. 459-464.

Shi, J. L., Kocaefe, D., and Zhang, J. (2007). "Mechanical behaviour of Quebec wood species heat-treated using ThermoWood process," Holz als Roh-und Werkstoff 65(4), 255-259.

Spycher, M., Schwarze, F. W. M. R., and Steiger, R. (2008). "Assessment of resonance wood quality by comparing its physical and histological properties," Wood Sci. and Technol. 44(4), 325-342. DOI: 10.1007/s00226-007-0170-5.

Stoel, B. C., and Borman, T. M. (2008). "A comparison of wood density between classical Cremonese and modern violins," PLOS ONE 3(7), 2554. DOI: 10.1371/journal.pone.0002554

ThermoWood®Handbook, (2003). Finnish Thermowood Association, Helsinki, Finland.

Viitaniemi, P., Jämsä, S., Ek , P., and Viitanen, H. (1997). "Method for improving biodegradation resistance and dimensional stability of cellulosic products," U.S. Patent No. 545791, 13.5.1994, 18 pp., US5678324A, USA

Windeisen, E., Bähle, H., Zimmer, B., and Wegener, G., (2009). "Relation between chemical changes and mechanical properties of thermally treated wood," Holzforschung 63(6), 773-778. DOI: 10.1515/HF.2009.084

Zauer, M., Sproßmann, R., and Wagenführ, A. (2014). "Improvement of the acoustic properties of European beech to substitute hard maple for the use in musical instruments," Proceedings of the Seventh European Conference on Wood Modification ECWM7, Lisbon, Portugal.

Zawadzki, J., Radomski, A., and Gawron, J. (2013). "The effect of thermal modification on selected physical properties of wood of scots pine (Pinus sylvestris L.)," Wood Research 58(2), 243-250.

Zhang, S. Y. (1997). "Wood specific gravity-mechanical property relationship at species level,” Wood Sci. Technol. 31(3), 181-191. DOI: 10.1007/BF00705884

Article submitted: August 10, 2019; Peer review completed: November 3, 2019; Revised version received: November 18, 2019; Accepted: November 19, 2019; Published:

December 2, 2019.

DOI: $10.15376 /$ biores.15.1.505-516 